\title{
Effect of the concentrate-based finishing on the proximate composition, organoleptic quality and fatty acids profile of the Beni-Guil sheep meat
}

\author{
Kamal Belhaj ${ }^{1,2, *}$, Farid Mansouri ${ }^{1}$, Marianne Sindic ${ }^{2}$, Yassine Taaifi ${ }^{1}$, Mohamed Boukharta ${ }^{3}$, Hana Serghini- \\ Caid $^{1}$, and Ahmed Elamrani ${ }^{1}$. \\ ${ }^{1}$ Laboratory for Agricultural Productions Improvement, Biotechnology and Environment (LAPABE), Faculty of Sciences, \\ University Mohammed First, BP-717, 60000 Oujda, Morocco. \\ ${ }^{2}$ Analysis Quality and Risk Unit, Laboratory of Food Quality and Safety (QSPA), Gembloux Agro-Bio Tech, University of \\ Liège, 5030 Gembloux, Belgium. \\ ${ }^{3}$ Institute of Agricultural Industries, High school of Charlemagne, 4500 Huy, Belgium.
}

\begin{abstract}
The aim of this study is to compare two sheep farming practices (lamb farming with or without finishing period on concentrate), on carcass characteristics, fatty acid profile and organoleptic quality of the meat. The study was performed on 24 Beni-Guil lambs. Finished animals (F) had access to creep feeding until weaning and were fed a mixed ration of barley and alfalfa hay during a finishing period of 45 days; however, nonfinished animals (NF) remained on the pasture. This comparison was carried out by analyzing the carcass characteristics, proximate composition and fatty acids profile of the meat. Ultimate $\mathrm{pH}$ and meat lightness were lower for F-lambs than NF-lambs who didn't go through the finishing period. The concentrate-based finished practice produced carcasses with better fatness state and conformation. The intramuscular fat content is more important in finished-lambs' meats (3.81 vs 1.82 ) which show more juiciness and a high meat's color lightness. However, meats of NF-lambs presented a high proportion of polyunsaturated fatty acids (PUFA: 20.70 vs 16.82 ), particularly the PUFA n-3 (3.97 vs 1.17 ) and consequently a low $n-6 / n-3$ ratio (3.92 vs 12.72 ). Finally, we recommend, finished lamb meats for the large-scale market and meat of pasture-raised lamb for the niche market.
\end{abstract}

\section{Introduction}

In Morocco, the trend in the distribution and consumption of sheep meat has changed considerably in recent years, both in terms of quality and quantity. The consumption and the price of fresh sheep meat depend on certain specific qualities and labels when it is intended for a target or niche market (small scale production of pasture lambs), but also influenced by its cost price and household incomes when it is intended for markets of large distribution (lambs raised under an intensive production system in which heavy carcasses are produced). Generally, in Morocco, traditional production is still dominant and sheep husbandry is performed with local breeds, using traditional methods based on pastures with pastoralism practices. In this system of traditional production, the sheep proliferate according to the natural reproduction period and lambs suckle their mothers until the age of weaning ( 3 months). As a rule in Morocco, where the lambs are slaughtered at 6-8 months of the animals are fattened ranging from 30 to 45 days before slaughter, to increase the slaughter live weight and to improve the aesthetic quality (commercial quality) of the lamb's carcass, depends on market demand.

Consumers of red meat tend to prefer lamb meat from pasture, considering that such lamb meat is much healthier, tastier, and more natural than meat from concentrate-based production systems. The meat quality is influenced by several factors such as the feeding system, breeding conditions, rearing season, and age at slaughter. Ekiz, Demirel [1], Ricardo, Fernandes [2], and Yalcintan, Ekiz [3] have shown that lamb meats produced under a concentrate-based system generally presents have higher carcass yield, better carcass conformation, and high fatness state. However, other authors indicate that meat from grazed lambs has a darker color and shows more favorable fatty acids profile than meat from the concentrate-fed system[4-6]. BeniGuil-

*Corresponding author: belhaj.kama190@gmail.com; k.belhaj@ump.ac.ma 
PGI Lamb meat is the main sheep meats produced in the eastof Morocco.It is very appreciated by the consumer because of its taste and its nutritional quality[7]. This has been revealed in our previous studies concerning the carcass and meat physicochemical characteristics of Beni-Guil sheep [7,8]. In this study, we supposed that the fatness state has significant effects on the meat quality and the fatty acids profile of the Beni-Guil sheep meat. For this purpose, we investigated the effect of the concentrate-based finishing period (indoor finishing on concentrate and alfalfa hay (F); raising on pasture without finishing phase (NF)) on the fatty acids profile and organoleptic quality. Except for our previously published works, no others studies have evaluated the variation of meat quality of Beni-Guil sheep reared in Eastern Morocco according to the two common finishing strategies.For this purpose, we investigated the effect of the concentrate-based finishing period (indoor finishing on concentrate and alfalfa hay (F); raising on pasture without finishing phase (NF)) on carcarss traits, organoleptic proprieties and fatty acids profile of Beni-Guil sheep meat.

\section{Material and methods}

\subsection{Animal material and Experimental design}

We compare two finishing strategies ( $\mathrm{n}=12$ for each group): (1)raising on pasture with indoor finishing period (45 days) on concentrate and alfalfa hay (F); (2) raising on pasture without finishing period (NF). The lambs were weaned at the age of 3 monthsand slaughtered at 7 months of age.

The study was carried out on twenty-four Longissimus lumborum (LLM) muscles of twenty-four female lambs of Beni-Guil sheep breed $(n=24)$. The animals used in this study were born and raised in the Ain-Beni-Mathar region in the south-east of Morocco. The choice of female lambs was made randomly from the same breeders in the two treatments. Before treatment, the studied animals were 5.5 months old, and after the treatments, the lambs were slaughtered at an age of 7 months with a live weight of $34.11 \mathrm{~kg} \pm 3.2$ and $25.67 \mathrm{~kg} \pm 2.31$, respectively for the finished and unfinished lambs. The finishing period based on concentrate-feed (barley and alfalfa hay: ( 1 to $1.5 \mathrm{~kg}$ /day) for 45 days was the only difference between the animals of the two studied treatments. The slaughter procedure was carried out according to the conventional Islamic method (bleeding, skinning, pollarding, evisceration, slot, post-mortem inspection, refrigeration).

\subsection{Objective and subjective carcass measurements}

Carcass measurements and observations included fatness state and carcass conformation for prediction of lamb carcass quality, were subjectively evaluated under the supervision of a veterinarian and according to the European system (EUROP) as described byCarrasco, Ripoll [9]. Carrasco, Ripoll [7]. The live weight (LW) and cold carcass weight $(\mathrm{CCW})$ are used to calculate the carcass yields or commercial yield $(\mathrm{CY})$ using the following formula: $\mathrm{CY}=(\mathrm{CCW} / \mathrm{LW}) \times 100$

\subsection{Analytical methods}

\subsubsection{Evaluation of meat quality}

The meat ultimate $\mathrm{pH}\left(\mathrm{pH}_{24}\right)$ was measured in Longissimuslumborum muscle (LLM), using a pH meter with a penetration probe. The meat color was estimated according to the international center of lighting using the CIELAB system using a Chromameter 400 Konica Minolta CR400(L* $=$ Lightness, $\mathrm{a}^{*}=$ Redness, $\mathrm{b} *=$ Yellowness) [10]. The meat juiciness was estimated by the application of a mechanical force. The samples were sliced into $1 \mathrm{~cm}$ thick steaks, with a diameter of $4 \mathrm{~cm}^{2}$, placed between 18 pre-weighed Whatman papers. The water holding capacity (WHC) was calculated as the difference in sample weight before and after applying a mechanical force of $2.250 \mathrm{Kg}$ for 5 min following the method described by Grau and Hamm [11]:

$$
\text { WHC }(\%)=[(\mathrm{IWM}-\mathrm{FWM} / \mathrm{FWM}) * 100]
$$

Where IWM: Initial weight of the meat, FWM: Final weight of the meat

\subsubsection{Samples preparation}

Strip loin cuts were collected from carcasses of Beni-Guil female Lambs 24hourspost-mortem in LLM. The samples were lyophilized and stored at $-20^{\circ} \mathrm{C}$ for ulterior analyses.

\subsubsection{Proximate composition}

Dry matter was determined by drying in a stove at $100{ }^{\circ} \mathrm{C} \pm 3{ }^{\circ} \mathrm{C}$ according to the Association of Official Analytical Chemists (AOAC)[12]. Intramuscular fat (IMF) was extracted and quantified according to Bligh and Dyer [13]. Ash was measured by incineration in the oven according to AOAC[12]. Total proteins were calculated according to the Kjeldahl method using the conversion index of 6.25 [12].

\subsubsection{Fatty acids profile analysis}

Before the lipid profile analysis, the extracted intramuscular fat was methylated to fatty acids methyl esters (FAME) using BF3 at 14\% weight in methanol [14]. The Agilent gas chromatography (GC: HP6890 series, Agilent Technologies, USA) coupled with a flame ionization detector (FID) was used to analyze the fatty acids 
profile, using the Helium as carrier gas (flow rate: $1.7 \mathrm{ml} / \mathrm{min}$ ). The GC-FID was equipped with a capillary column Omega wax type (length column: $30 \mathrm{~m}$; Diameter: $0.25 \mathrm{~mm}$; film thickness: $0.25 \mu \mathrm{m}$ ). The temperatures of the injector and the detector were set at 150 and $250{ }^{\circ} \mathrm{C}$, and the oven temperature was at $210{ }^{\circ} \mathrm{C}$. The injection mode used was the splitless type by injecting a volume of $1 \mu \mathrm{L}$. A fatty acid methyl esters standard, containing 37 components (Supelco, Bellefonte, PA, USA), was used to identify the individual peaks. The average percentage of each fatty acid was used to calculate the sum, ratios, and lipid indices of the meat.

\subsection{Statistical analyses}

Theobtained results weregiven as means \pm standard deviation of triplicate determinations. The statistical analyses were carried out using the software SPSS version 20while considering the finishing strategy as a source of variation. The means were compared using the $t$-test and the significance was declared at $p<0.05$.

\section{Results and discussion}

The effects of the finishing period on carcass traits, organoleptic quality of meat, and the fatty acids profile are presented in Tables 1, 2, 3, and 4 .

\subsection{Carcass characteristics}

The carcass yield is an important criterion for the assessment of carcass commercial-quality in rearing sheep destined to meat production. This parameter (dressing percentage) allows the professional to predict the potential commercial transactions of the carcass (profitability)[8].The results indicate that the finished animals (group F) hada higher $(p<0.001)$ cold carcass weight $(16.37 \mathrm{~kg}$ vs $11.55 \mathrm{~kg})$ with higher commercial yield percentage than those not finished (group NF) (48.43 vs 45.11; Table 1). A similar result was obtained by several researchers [1, 3,5]. Borton, Loerch [15], and Karim, Porwal [16]reported that the intensive production systems produce animals with a higher dressing percentage compared to extensive systems. They explain this result by the digestive tract which is more developed in animals produced extensively due to the higher coarse food compared to those produced intensively. The finishing period had a significant effect on the carcass' subjective characteristics $(p<0.001)$. Moreover, $\mathrm{F}$ animals have shown a higher $(p<0.001)$ fatness state $(3.51$ vs 1.61$)$ and conformation score (2.82 vs 1.42; Table 1).Previous studieshavereported that animals from production systems based on concentrate-fed produce carcasses with higher fatness and conformation scores due to (i) the consumption of energy-rich food ration (barley), and also due to (ii)the physical activity or the greater energy expenditure of grazing lambs toobtain food $[1,3,5,17]$.

Table 1. Finishing period effect on the carcass characteristics of Beni-Guil sheep meat

\begin{tabular}{|c|c|c|c|}
\hline \multirow{2}{*}{ Parameters } & \multicolumn{2}{|c|}{ Finishing period } & \multirow{2}{*}{ P-value } \\
\cline { 2 - 4 } & Lambs Group F & Lambs Group NF & 0.000 \\
\hline Live weight at slaughter (kg) & $34.11 \pm 2.63$ & $25.67 \pm 3.1$ & 0.002 \\
\hline Commercial yeild (\%) & $48.43 \pm 0,03$ & $45.11 \pm 0.01$ & 0.000 \\
\hline Fatness score & $3.51 \pm 0,46$ & $1.61 \pm 0.32$ & 0.002 \\
\hline Conformation score & $2,82 \pm 0,12$ & $1.42 \pm 0.13$ & \\
\hline
\end{tabular}

Group $\mathrm{F}=$ indoor finishing lambs on barley and alfalfa hay; Group $\mathrm{NF}=$ lambs raised on pasture without finishing period; Conformation: Excellent $=5$;Very good $=4$;Good $=3$;Fair $=2$; Poor $=1$;Fatness score: $1=$ Very low; $2=$ Low; 3 Average; $4=$ High; $5=$ Very high;

\subsection{Organoleptic quality}

Meat $\mathrm{pH}$ is a chemical parameter that determines the final quality of the meat and has direct and indirect effects, practically, on the meat's organoleptic properties $[8,18]$. The obtained values varied between 5.7 and 5.8 . These recorded values were within the normal ranges for commercial meats [19].The meat from $F$ lambs had a lower $(p<0.05) \mathrm{pH}_{24}$ values than that of NF animals (Table 2).Grazing lambs are associated with low energy forage diets (low energy ration) and have relatively small glycogen reserves compared to intensively reared lambs. Similar results were reported by several authors[3,5,6]. This difference could be explained by the quantity ofconcentrated food ingested by lambs finished with barley and alfalfa hay which promotes the propionic fermentation in the rumen and consequently, the production of propionic acid (precursor of muscle glycogen).

Meat juiciness is among the main intrinsic factors influencing meat palatability and acceptability[17-18]. The NF lambs show the highest values of WHC $(23.96 \%$ vs $15.91 \% ; p>0.001)$. This recorded difference could be explained by the quantity of intramuscular fat and by the quantity of water from the food ration ingested by the 
animals (more grazing $=$ more water in the meat).Priolo, Micol [17]reported that fat content is positively correlated to meat juiciness and that grazing lambs produces carcasses with lower fat content due to the consumption of a low energy diet and intense physical activity. Hence, it could be concluded that the meat of finished animals would be morejuicious than that of unfinished ones.

Meat color or visual appearance is the defining quality of its buying, which is mainly associated with its freshness $[20,21]$. Consumers of ruminant meat prefer bright red meat and associate it with high quality and product freshness. The color coordinates (lightness, redness, yellowness, chroma, and hue angle) are presented in Table 2. The lightness values ( $\mathrm{L}^{*}$ ) for the two studied groups, ranging between 37.03 and 34.15 are indicative of bright red color[22]. Meat color can be influenced by numerous factors such as intramuscular fat, ultimate $\mathrm{pH}$, myoglobin content, and its chemical state, physical activity, age, and live weight at slaughter [17, 23-25]. The meat of NF lambs was darker than that of F lambs. Similar results were reported by Diaz, Velasco [26] and Yalcintan, Ekiz[3] on lamb's meat. No differences were found in the yellowness index $(p>0.05)$. The greater values of the $\mathrm{L}^{*}$ index were recorded in the meat of $\mathrm{F}$ animals (37.03 vs 34.15$)$. This result can be ascribed to intramuscular fat which increases the meat lightness and the physical activities associated with pasture. Diaz, Velasco [26], Cartier and Moevi [27] and Yalcintan, Ekiz [3] reported that pasture-fed animals produced darker meat (lower $\mathrm{L}^{*}$ ) due to a higher myoglobin content and lower intramuscular fat and they explained this difference by physical activity, higher myoglobin content in animals raised on pasture and low energy diet (less intramuscular fat). Moreover, lambs raised on pasture contain a high concentration of oxidative type I muscle fibers, which are rich in myoglobin and contribute to a higher muscular myoglobin content. Continuous physical exercise, associated with extensive rearing systems, induces the transition of glycolytic muscle fiber (fast-twitch fibers) to oxidative muscle fiber (slow-twitch fibers) [5]

Table 2. Finishing period effect on the proximate composition and meat quality characteristics of Beni-Guil sheep meat

\begin{tabular}{|c|c|c|c|}
\hline \multirow[b]{2}{*}{ Parameters } & \multicolumn{2}{|c|}{ Finishing period } & \multirow{2}{*}{$P$-value } \\
\hline & Lambs Group F & Lambs Group NF & \\
\hline \multicolumn{4}{|l|}{ Proximate composition } \\
\hline Dry matter $(\%)$ & $25,71 \pm 1,99$ & $24.51 \pm 0.28$ & 0.328 \\
\hline Total protein $(\%)$ & $21,41 \pm 0,56$ & $21.61 \pm 0.56$ & 0.561 \\
\hline Intramuscular Fat (\%) & $3,82 \pm 1,72$ & $1.82 \pm 0.13$ & 0.002 \\
\hline Ash $(\%)$ & $1,02 \pm 0,06$ & $1.05 \pm 0.01$ & 0.118 \\
\hline \multicolumn{4}{|l|}{ Organoleptic quality } \\
\hline Ultimate $\mathrm{pH}\left(\mathrm{pH}_{24}\right)$ & $5,72 \pm 0.2$ & $5.8 \pm 0.16$ & 0.034 \\
\hline WHC $=($ Expressed Juiciness $(\%))$ & $15,91 \pm 1,23$ & $23.96 \pm 2.05$ & 0.000 \\
\hline \multicolumn{4}{|l|}{ Meat color } \\
\hline Lightness $\left(\mathrm{L}^{*}\right)$ & $37,03 \pm 1,31$ & $34.15 \pm 1.24$ & 0.000 \\
\hline Redness ( $\left.\mathrm{a}^{*}\right)$ & $12,62 \pm 0,96$ & $13.33 \pm 0.49$ & 0.497 \\
\hline Yellowness $\left(\mathrm{b}^{*}\right)$ & $13,43 \pm 0,79$ & $13.24 \pm 0.56$ & 0.056 \\
\hline Chromaticity $\left(\mathrm{C}^{*}\right)$ & $18,46 \pm 0.75$ & $18.79 \pm 0.64$ & 0.278 \\
\hline Hue angle $^{\circ}$ & $46,80 \pm 3,14$ & $44.80 \pm 1.13$ & 0.035 \\
\hline $\mathrm{a} * / \mathrm{b}^{*}$ & $0,94 \pm 0.1$ & $1 \pm 0.04$ & 0.040 \\
\hline
\end{tabular}

Group $\mathrm{F}=$ indoor finishing lambs on barley and alfalfa hay; Group $\mathrm{NF}=$ lambs raised on pasture without finishing period; IMF: Intramuscular Fat; WHC: Water holding Capacity; the scale of $a^{*}, b^{*}, L^{*}: a^{*}$ and $b^{*}: 60$ to 60, $L^{*}: 0$ to 100. Scales of chroma and hue: chroma: 0-60, hue: $0-360$.

\subsection{Proximate composition}

The proximate composition of the LL muscle of the studied groups is given in Table 2. Regarding the intramuscular far (IMF), the results show that $\mathrm{F}$ lambs have higher $(p<0.01)$ fat content than NF lambs $(3.82$ vs 1.82). Similar results were found by Ekiz, Demirel [1] and Priolo, Micol [17]. Intensive production systems produce carcasses with higher IMF content than extensive production systems. The concentrate-fed production system is associated with high energy diets (high nutrition level) and consequently a high intramuscular fat. Also, these results could be attributed to the limited exercise associated with intensive production systems[26].Intramuscular fat also has a positive effect on meat juiciness (increasing the sustained juiciness), tenderness (dilution of muscle fibers), and flavor (Flavor carrying components are hydrophobic and are therefore dissolved in fat) of the meat[5]. As a result, the meat of $\mathrm{F}$ animals will be more tender and juicer with better 
flavor. No significant effect has been shown regardingdry matter, protein content, and ash ( $p>0.05)$.Numerous authors support our findings and have concluded that production systems had no effect on dry matter, crude protein, and ash[28, 29].

\subsection{Fatty acids profile analysis}

Tables 3 and 4 present the effect of concentrate-based finishingon the fatty acids profile of LLM of Beni-Guil sheep meat. The predominant fatty acid was C18:1, followed by C16:0, C18:0, and C18:2n6. Total saturated fatty acids were present at higher proportions than monounsaturated fatty acids, with the lowest proportions corresponding to polyunsaturated fatty acids. In general, the values were similar to others reported for Beni-Guil sheep breed[7, 30].The prevailing individual fatty acids (FA) were oleic acid, followed by palmitic, stearic, and linoleic. The saturated fatty acids (SFA) present the highest proportion of total fatty acids in the meat of NF lambs, while the monounsaturated (MUFA) fatty acids dominate the profile of F lambs meat (42 vs $40 \mathrm{vs} 16 \%$ respectively for MUFA, SFA, and PUFA).

Table 3.Finishing period effect on the fatty acids profile of Beni-Guil sheep meat

\begin{tabular}{|c|c|c|c|}
\hline \multirow[b]{2}{*}{ Fatty acids (\%) } & \multicolumn{2}{|c|}{ Finishing period } & \multirow{2}{*}{$P$-value } \\
\hline & Lambs Group F & Lambs Group NF & \\
\hline C10:0 & $0.12 \pm 0.05$ & ND & - \\
\hline $\mathrm{C} 12: 0$ & $0.15 \pm 0.06$ & ND & - \\
\hline $\mathrm{C} 13: 0$ & $0.02 \pm 0.00$ & ND & - \\
\hline C14:0 & $1.88 \pm 0.32$ & $1.62 \pm 0.3$ & 0.116 \\
\hline $\mathrm{C} 14: 1$ & $0.22 \pm 0.02$ & $0.31 \pm 0.06$ & 0.451 \\
\hline $\mathrm{C} 15: 0$ & $0.4 \pm 0.11$ & $0.40 \pm 0.03$ & 0.989 \\
\hline $\mathrm{C} 15: 1$ & $0.13 \pm 0.01$ & $0.25 \pm 0.01$ & 0.041 \\
\hline $\mathrm{C} 16: 0$ & $20.47 \pm 1.15$ & $19.58 \pm 0.12$ & 0.010 \\
\hline $\mathrm{C} 16: \ln 7$ & $0.35 \pm 0.04$ & $0.39 \pm 0.02$ & 0.027 \\
\hline $\mathrm{C} 16: \ln 9$ & $1.97 \pm 0.35$ & $1.45 \pm 0.8$ & 0.050 \\
\hline $\mathrm{C} 17: 0$ & $1.5 \pm 0.62$ & $0.91 \pm 0.02$ & 0.010 \\
\hline $\mathrm{C} 17: 1$ & $1.09 \pm 0.28$ & $1.01 \pm 0.02$ & 0.259 \\
\hline C18:0 & $15.15 \pm 0.89$ & $16.14 \pm 0.25$ & 0.001 \\
\hline Cis/trans-C18:1n9 & $38.26 \pm 3.43$ & $34.38 \pm 0.83$ & 0.001 \\
\hline Cis/trans-C18:2n6 & $9.33 \pm 2.82$ & $8.54 \pm 0.76$ & 0.327 \\
\hline C18:3n6 & $0.8 \pm 0.07$ & $1.99 \pm 0.02$ & 0.000 \\
\hline C18:3n3 & $0.45 \pm 0.1$ & $0.64 \pm 0.03$ & 0.001 \\
\hline $\mathrm{C} 20: \ln 9$ & $0.18 \pm 0.03$ & $0.27 \pm 0.01$ & 0.577 \\
\hline $\mathrm{C} 20: 2$ & $0.6 \pm 0.2$ & $1.14 \pm 0.02$ & 0.000 \\
\hline C20:3n6 & $0.39 \pm 0.1$ & $0.6 \pm 0.03$ & 0.003 \\
\hline $\mathrm{C} 20: 3 \mathrm{n} 3$ & $0.08 \pm 0.02$ & ND & - \\
\hline C20:4n6 & $4.42 \pm 1.34$ & $4.45 \pm 0.45$ & 0.957 \\
\hline $\mathrm{C} 20: 5 \mathrm{n} 3$ & $0.42 \pm 0.02$ & $2.16 \pm 0.02$ & 0.000 \\
\hline $\mathrm{C} 22: 2$ & $0.11 \pm 0.09$ & ND & - \\
\hline C23:0 & $0.28 \pm 0.1$ & $0.40 \pm 0.03$ & 0.001 \\
\hline $\mathrm{C} 24: 0$ & $0.76 \pm 0.05$ & $2.09 \pm 0.3$ & 0.000 \\
\hline C22:6n3 & $0.21 \pm 0.02$ & $1.17 \pm 0.2$ & 0.000 \\
\hline $\mathrm{C} 24: \ln 9$ & $0.25 \pm 0.02$ & ND & - \\
\hline
\end{tabular}

Group $\mathrm{F}$ = indoor finishing lambs on barley and alfalfa hay; Group NF = lambs raised on pasture without finishing period; NS: not significant; ND: not detected

The fatty acid profile of finished lambs was different from the not-finished ones.The concentrate-based finishing period had significant effects $(p<0.05)$ on individuals, sums, ratios, and indices of fatty acids (Tables 3 
and 4). Also, our findings show that the finishing period can significantly affect certain saturated fatty acids such asC17:0.High concentration of heptadecanoic acid ( $\mathrm{C} 17: 0)$ recorded in the meat of $\mathrm{F}$ animals could be attributed to the greater ingestion of concentrate, which promotes the rumen bio-hydrogenationand, consequently, the synthesis of volatile fatty acids, particularly the propionic acid (precursor of odd fatty acids)[31]. F animals'meatcontains the highest proportion of MUFA and the lowest percentage of polyunsaturated fatty acids (PUFA).The difference in MUFA fraction is mainly due to the percentage ofC18:1), which is considered as a beneficial FA [32]. The finished lambshave a higher content of C18:1 (38.26\% vs $34.38 \%$; $p=0.001)$. This difference can be explained by the nature of the feeding system characterized by its concentraterichness (barley) in the finishing period, which decreases the stay of feed-in rumen, thus decreasingthe bio-hydrogenation of unsaturated fatty acids[33]. Similar results were reported by Scerra, Caparra [34] in milk from ewesfeeded by concentrate and pasture.Regarding the PUFA fraction, the meat from NF lambs shows the highest percentage $(16.82 \%$ vs $20.70 \%)$, leading them to a more favorable PUFA/SFA ratio (0.42 vs 0.5$)$. This difference mainly concernsPUFAn-3content ( $1.17 \%$ vs $3.97 \%$, respectively for F and NF), and particularly the proportion of C20:5 $(0.42 \%$ vs $2.16 \%)$ respectively for $\mathrm{F}$ and NF animals). As a consequence, this highest concentration of PUFA n-3 resulted in a significant reduction of $n-6 / n-3$ ratio $(12.76$ vs $3.97 ; p<0.001)$. This difference can be attributed tothe pasture-fed system, which is richer in PUFA n-3 than the concentrate-fed system; particularly, the linolenic acid amount is high in herbage. Several authors have also suggested that the pasture rearing system produces meat with favorable PUFA/SFA and n-6/n-3 ratio, compared to those reared under concentrate-fed production system[5, 26, 34, 35].In accordance with our results, Scerra, Caparra [34], Biondi, Valvo [36], and Mazzone, Giammarco [37] have also demonstrated that a diet based exclusively on green herbage, compared to a concentrate based feed, leads to a favorable PUFA/SFA and n-6/n-3 ratio.Concerning the lipid health indices ( $($ Thrombogenicity Index $=(\mathrm{TI})$, Atherogenicity Index $=(\mathrm{AI}))$, which should not exceed the value of 1 [31], the not finished animals present the favorable indices inferior to 1 . The registered results for the two studied groups are comparable to those reported by Sinanoglou, Batrinou [32] for Greek lambs.

The nutritional recommendations for humans in terms of lipid diet are to reduce total lipid intake,specifically the SFA and rebalance the PUFA ratio of the n- 6 and n-3 series by increasing the intake of n-3[38, 39].The recommendation in human nutrition suggests that the n-6/n-3 ratio should be between 2 and 4[38]. So, from the dietary point of view, the $\mathrm{F}$ lambs present the disadvantage of a lower concentration of $\mathrm{n}-3$ fatty acids, a thrombogenic index superior to the recommended value, and, consequently, a higher $n-6 / n-3$ ratio in comparison to the NF lambs.

Table 4. Finishing period effect on the sums, ratios, and indices of fatty acids profile of Beni-Guil sheep meat

\begin{tabular}{|c|c|c|c|}
\hline \multirow{2}{*}{ Sums and ratios of FAs } & \multicolumn{2}{|c|}{ Finishing period } & \multirow{2}{*}{ P-value } \\
\cline { 2 - 4 } & Lambs Group F & Lambs Group NF & 0.411 \\
\hline SFA & $40.73 \pm 2.33$ & $41.26 \pm 0.51$ & 0.001 \\
\hline MUFA & $42.44 \pm 4.02$ & $38.04 \pm 0.9$ & 0.028 \\
\hline PUFA & $16.82 \pm 5.98$ & $20.70 \pm 1.00$ & 0.411 \\
\hline UFA & $59.26 \pm 2.33$ & $58.74 \pm \pm 0.3$ & 0.256 \\
\hline DFA & $74.42 \pm 1.5$ & $77.88 \pm 0.16$ & 0.105 \\
\hline OFA & $3.14 \pm 1.01$ & $2.67 \pm 0.18$ & 0.321 \\
\hline UFA/SFA & $1.46 \pm 0.14$ & $1.42 \pm 0.01$ & 0.091 \\
\hline PUFA/SFA & $0.42 \pm 0.16$ & $0.50 \pm 0.01$ & 0.663 \\
\hline PUFA n-6 & $14.94 \pm 3.34$ & $15.58 \pm 0.85$ & 0.000 \\
\hline PUFA n-3 & $1.17 \pm 0.37$ & $3.97 \pm 0.55$ & 0.000 \\
\hline n-6/n-3 & $12.72 \pm 2.2$ & $3.92 \pm 0.22$ & 0.000 \\
\hline TI & $1.16 \pm 0.13$ & $0.96 \pm 0.02$ & 0.083 \\
\hline AI & $0.47 \pm 0.05$ & $0.44 \pm 0.02$ & 0.162 \\
\hline h/H & $2.49 \pm 0.28$ & $2.61 \pm 0.06$ & 0.450 \\
\hline Nutritive value & $2.6 \pm 0.12$ & $2.58 \pm 0.03$ & \\
\hline
\end{tabular}

Group $\mathrm{F}$ = indoor finishing lambs on barley and alfalfa hay; Group $\mathrm{NF}$ = lambs raised on pasture without finishing period; Lambs group F: With the finishing period; Lambs group NF: Without the finishing period; SFA: Saturated fatty acids; UFA: Unsaturated fatty acids; PUFA: Polyunsaturated fatty acids;DFA: Desirable Fatty Acids (C18:0 + UFA); OFA: Odd Fatty Acids;IT $=$ Thrombogenic Index [C14:0+C16:0+C18:0] / $\left[(0.5 *\right.$ MUFA $\left.)+\left(0.5 * \sum n-6\right)+\left(3 * \sum n-3\right)+(n-3 / n-6)\right]$; IA $=$ Atherogenic Index $\left[\left(4^{*} \mathrm{C} 14: 0\right)+\mathrm{C} 16: 0\right] /[(\mathrm{PUFA})+(\mathrm{MUFA})]$, calculated as per Ulbrichtet Southgate (1991) without the 
inclusion of 18:0 which is considered to be neutral on serum cholesterol; $\mathrm{h} / \mathrm{H}=$ Hypocholesterolemic $(\mathrm{h}) /$ Hypercholesterolemic $(\mathrm{H}) ; \mathrm{h} / \mathrm{H}=(18: \ln 9 \mathrm{c}+18: 2 \omega 6+20: 4 \omega 6+18: 3 \omega 3+20: 5 \omega 3+22: 5 \omega 3+22: 6 \omega 3) /(14: 0+16: 0)$; Nutritive value:(C18:0+C18:1) $/ \mathrm{C} 16: 0$

\section{Conclusion}

Two farming practices for lambs' fattening were studied, a pasture rearing supplemented with indoor finishing on concentrate (F) during 45 days compared to lambs' fattening exclusively on pasture (NF). The results show that concentrate-based finished lambs have better subjective carcass traits and better meat juiciness. However, nonfinished lambs (raised on pastures, without going through the finishing period) show meat with a better fatty acid profile and well-balanced ratios of PUFA/SFA and omega-6/omega-3. Thus, from an organoleptic point of view but especially from a productivity and economic profitability point of view, the meats of finished lambs based on concentrate are recommended for the mass market. However, from a nutritional and dietetic point of view, the meats of lambs exclusively pasture-raised will be recommended for the niche market, where informed consumers look for less fat meats with high nutritional quality, even if, because they are less fat, their organoleptic quality is slightly lower than that of the previous ones and cost more.

Currently, it is recommended to provide consumers with products of consistent quality to enhance their confidence in the product and encourage repurchases. Therefore, it is crucial to investigate the full impact of the two production practices $(\mathrm{F}, \mathrm{NF})$ to better understand the finishing strategy effects and its duration on the meat quality characteristics of Beni-Guil sheep meat to ensure that the quality is maintained and that consumer expectations are met. Thus, to enhance the quality of the meat's IMF of finished lambs (F), particularly PUFA n3 , it is essential to improve the composition of their diet such as the incorporation of seeds rich in PUFA n-3.

\section{References}

1. B. Ekiz, G. Demirel, A. Yilmaz, M. Ozcan, H. Yalcintan, O. Kocak, and A. Altinel, Small Ruminant Res., 114, 26-34 (2013)

2. H. Ricardo, A. Fernandes, L. Mendes, M. Oliveira, V. Protes, E. Scatena, R. Roça, N. Athayde, L. Girão, and L. Alves, Small Ruminant Res., 130, 141-145 (2015)

3. H. Yalcintan, B. Ekiz, O. Kocak, N. Dogan, P.D. Akin, and A. Yilmaz, Arch. Anim. Breed., 60, 225-233 (2017)

4. B. Aurousseau, D. Bauchart, X. Faure, A. Galot, S. Prache, D. Micol, and A. Priolo, Meat Sci., 76, 241-252 (2007)

5. Y. Hanekom, Stellenbosch: University of Stellenbosch, Sout Africa, 153 (2010)

6. A.G. D’Alessandro, G. Maiorano, M. Ragni, D. Casamassima, G. Marsico, and G. Martemucci, Small Ruminant Res., 114, 97-104 (2013)

7. K. Belhaj, F. Mansouri, M.-L. Fauconnier, M. Boukharta, H.S. Caid, M. Sindic, and A. Elamrani, Med. J. Nutrition Metab., 11, 175-185 (2018)

8. K. Belhaj, F. Mansouri, A. Tikent, A. Ouchatbi, M. Boukharta, C.H. Serghini, and A. Elamrani, Rev. Elev. Med. Vet. Pays Trop., 73, 21-26 (2020)

9. S. Carrasco, G. Ripoll, A. Sanz, J. Álvarez-Rodríguez, B. Panea, R. Revilla, and M. Joy, Livest. Sci., 121, 56-63 (2009)

10. H. Calnan, R. Jacob, D. Pethick, and G. Gardner, Meat Sci., 119, 41-50 (2016)

11. R. Grau and R. Hamm, Naturwissenschaften, 40, 29-30 (1953)

12. AOAC, Official Methods of Analysis of the Association of Official Analytical Chemists (Association of Official Analytical Chemists, Washington, 1990)

13. E.G. Bligh and W.J. Dyer, Can. J. Biochem. Physiol., 37, 911-917 (1959)

14. A. Ben moumen, Université Mohamed Premier, Morocco, 157 (2015)

15. R. Borton, S. Loerch, K. McClure, and D. Wulf, J. Anim. Sci., 83, 679-685 (2005)

16. S. Karim, K. Porwal, S. Kumar, and V. Singh, Meat Sci., 76, 395-401 (2007)

17. A. Priolo, D. Micol, J. Agabriel, S. Prache, and E. Dransfield, Meat Sci., 62, 179-185 (2002)

18. A. Valros, C. Munsterhjelm, E. Puolanne, M. Ruusunen, M. Heinonen, O.A. Peltoniemi, and A.R. Pösö, Acta Vet. Scand., 55, 75 (2013)

19. J.F. Tejeda, R.E. Peña, and A.I. Andrés, Meat Sci., 80, 1061-1067 (2008)

20. A. Clinquart, B. Leroy, O. Dottreppe, J. Hornick, I. Dufrasne, and L. Istasse, Les facteurs de production qui influencent la qualité de la viande des bovins Blanc Bleu belge, inProceedings of theJournée du Centre d'Excellence du Secteur agricole et son Management,CESAM, 26 Mai 2000,Mons, France(2000) 
21. M. Beriain, P. Bas, A. Purroy, and T. Treacher, Effect of animal and nutritional factors and nutrition on lamb meat quality, in Proceeding of the Cahiers Options Méditerranéennes, CIHEAM, 2000,Grignon, France (2000) .

22. C. Salifou, A. Youssao, G. Ahounou, P. Tougan, S. Farougou, G. Mensah, and A. Clinquart, Ann. Med. Vet., 157, 27-42 (2013)

23. R. Lawrie, Meat Sci., (Permgamon Press: Oxford, NY, 1966).

24. B. Ekiz, A. Yilmaz, M. Ozcan, and O. Kocak, Meat Sci., 90, 465-471 (2012)

25. J.-b. Liu, J. Guo, F. Wang, Y.-j. Yue, W.-1. Zhang, R.-1. Feng, T.-t. Guo, B.-h. Yang, and X.-p. Sun, Small Ruminant Res., 123, 251-259 (2015)

26. M. Diaz, S. Velasco, V. Caneque, S. Lauzurica, F.R. De Huidobro, C. Pérez, J. Gonzalez, and C. Manzanares, Small Ruminant Res., 43, 257-268 (2002)

27. P. Cartier and I. Moevi, Le point sur la qualité des carcasses et des viandes de gros bovins (Institut d'élevage, Paris, 2007)

28. A. Rowe, F. Macedo, J. Visentainer, N. Souza, and M. Matsushita, Meat Sci., 51, 283-288 (1999)

29. M. Pompa-Roborzynski and W. Kedzior, Arch Tierz, 49, 268-274 (2006)

30. K. Belhaj, F. Mansouri, M. Sindic, M.-L. Fauconnier, M. Boukharta, C.-H. Serghini, and A. Elamrani, JABS, 13, 166-171 (2019)

31. G. Oriani, G. Maiorano, F. Filetti, C. Di Cesare, A. Manchisi, and G. Salvatori, Meat Sci., 71, 557-562 (2005)

32. V.J. Sinanoglou, A. Batrinou, F. Mantis, I. Bizelis, and S. Miniadis-Meimaroglou, Small Ruminant Res., 113, $1-10(2013)$

33. I. Petrova, V. Banskalieva, and V. Dimov, Small Ruminant Res., 13, 263-267 (1994)

34. M. Scerra, P. Caparra, F. Foti, V. Galofaro, M. Sinatra, and V. Scerra, Meat Sci., 76, 390-394 (2007)

35. J. Wood, M. Enser, A. Fisher, G. Nute, F. Whittington, and R. Richardson, Cah. Options Mediterr., Series A, 67, 133-141 (2003)

36. L. Biondi, M. Valvo, M. Di Gloria, E.S. Tenghi, V. Galofaro, and A. Priolo, Small Ruminant Res., 75, 1723 (2008)

37. G. Mazzone, M. Giammarco, G. Vignola, L. Sardi, and L. Lambertini, Meat Sci., 86, 474-478 (2010)

38. A.P. Simopoulos, Biomed. Pharmacother., 56, 365-379 (2002)

39. N.L. Howes, A.E.D.A. Bekhit, D.J. Burritt, and A.W. Campbell, Compr. Rev. Food Sci. Food Saf., 14, 22$36(2015)$ 